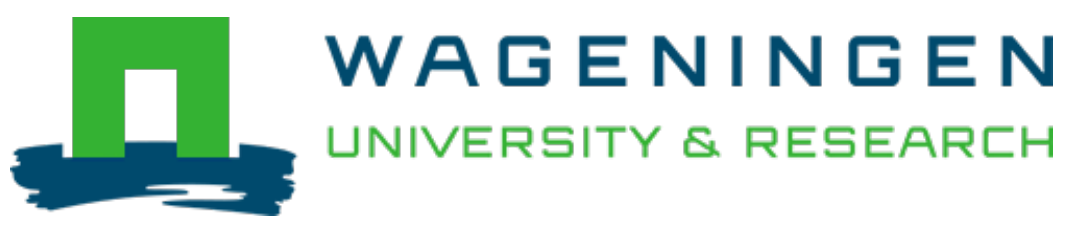

\title{
Biological control in the remaining Caribbean islands
}

Biological control in Latin America and the Caribbean

Lenteren, J.C.; Bueno, V.H.P.

https://doi.org/10.1079/9781789242430.0403

This article is made publicly available in the institutional repository of Wageningen University and Research, under the terms of article $25 \mathrm{fa}$ of the Dutch Copyright Act, also known as the Amendment Taverne. This has been done with explicit consent by the author.

Article $25 \mathrm{fa}$ states that the author of a short scientific work funded either wholly or partially by Dutch public funds is entitled to make that work publicly available for no consideration following a reasonable period of time after the work was first published, provided that clear reference is made to the source of the first publication of the work.

This publication is distributed under The Association of Universities in the Netherlands (VSNU) 'Article $25 \mathrm{fa}$ implementation' project. In this project research outputs of researchers employed by Dutch Universities that comply with the legal requirements of Article $25 \mathrm{fa}$ of the Dutch Copyright Act are distributed online and free of cost or other barriers in institutional repositories. Research outputs are distributed six months after their first online publication in the original published version and with proper attribution to the source of the original publication.

You are permitted to download and use the publication for personal purposes. All rights remain with the author(s) and / or copyright owner(s) of this work. Any use of the publication or parts of it other than authorised under article $25 \mathrm{fa}$ of the Dutch Copyright act is prohibited. Wageningen University \& Research and the author(s) of this publication shall not be held responsible or liable for any damages resulting from your (re)use of this publication.

For questions regarding the public availability of this article please contact openscience.library@wur.nl 


\section{Biological Control in the
Remaining Caribbean Islands}

Joop C. van Lenteren ${ }^{1 *}$ and Vanda H.P. Bueno ${ }^{2}$

'Laboratory of Entomology, Wageningen University, The Netherlands; ${ }^{2}$ Laboratory of Biological Control, Department of Entomology, Federal University of Lavras, Lavras, Minas Gerais, Brazil

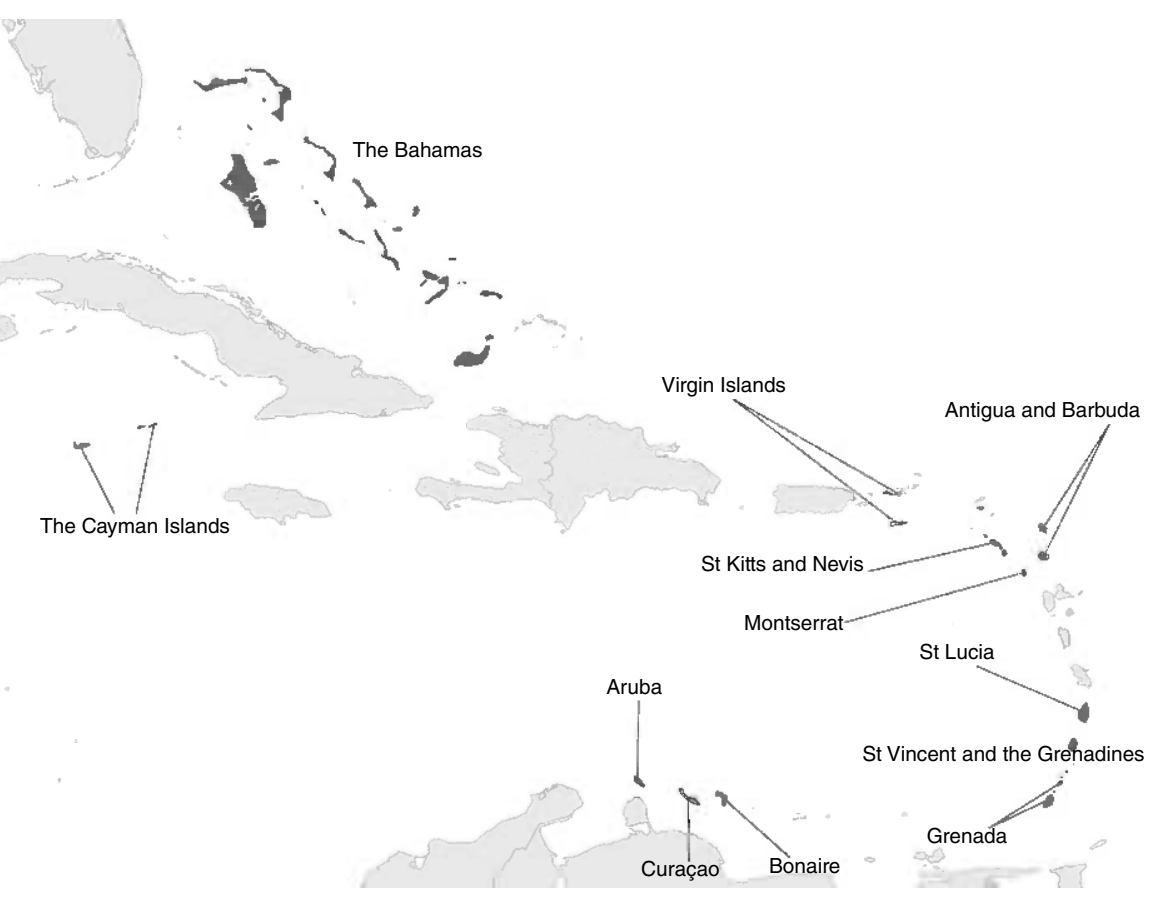

* E-mail: joop.vanlenteren@wur.nl 


\begin{abstract}
Biological control activities on 18 (groups of) Caribbean islands are summarized. Many natural enemies were introduced to these islands through Trinidad and Tobago up to 1980. Also, inter-island exchange of biocontrol agents took place. The majority of projects concerned classical biocontrol, while in some cases natural, conservation and augmentation biocontrol were used. Successes were obtained with biocontrol of pests in crops such as arrowroot, citrus, coconut, cotton and sugarcane and of weeds like prickly pear and puncture vine. After 1980, the number of natural enemy introductions decreased, though the region was faced with many invasions by exotic pests, including the citrus leaf miner, citrus blackfly, papaya mealybug, giant African snail, coconut whitefly and pink hibiscus mealybug. Two large region-wide programmes resulted in successful biocontrol of the pink hibiscus mealybug and the papaya mealybug. In addition, biocontrol by a native natural enemy complex was demonstrated for the coconut whitefly and the passion vine mealybug. The Food and Agriculture Organization of the United Nations (FAO) Code of Conduct for the Import and Release of Exotic Biological Control Agents has recently been applied in the region. Farmers Field Schools, with the aim to enable farmers to use IPM and become less dependent on chemical pesticides, are being implemented.
\end{abstract}

\subsection{Introduction}

In this chapter we summarize information about biological control carried out in 18 (groups of) small islands in the Caribbean Sea with a total population of about 1.2 million inhabitants. Though the volume of agricultural production is small, a surprising amount of biocontrol activities have been performed on these islands in the past and currently some large Caribbean-wide projects are being implemented. The history and current situation related to status (independent or not) of the islands are rather complicated and have changed a number of times during the past decades.

- Antigua and Barbuda (autonomous country, member of British Commonwealth) have an estimated population of almost 95,000 (July 2017) and their agricultural products - mainly for local use - are cotton, fruits, vegetables, bananas, coconuts, cucumbers, mangoes and sugarcane; there is some livestock production as well (CIA, 2018a).

- Aruba (Netherlands) has an estimated population of slightly more than 116,500 inhabitants (July 2018) and agriculture is an unimportant economic activity with as export products small amounts of aloe, livestock and fish (CIA, 2018b).

- The Bahamas (autonomous country, member of British Commonwealth) have an estimated population of almost 330,000 (2017) and their main agricultural products are citrus and vegetables; also poultry and seafood are produced (CIA, 2018d).
- Bonaire (Caribbean Netherlands) has an estimated population of almost 20,000, with some agricultural activities such as maize cropping, and fisheries (Wikipedia, 2019a; Landenweb, 2019).

- The Cayman Islands (autonomous country, member of British Commonwealth) have an estimated population of almost 60,000 (2018) with very limited agricultural activities, which include vegetables and fruit; there is some livestock and turtle farming (CIA, 2018e).

- Curaçao (Netherlands) has an estimated population of more than 150,000 (July 2018) and agriculture is an unimportant economic activity, with as export products small amounts of aloe, sorghum, peanuts, vegetables and tropical fruit (CIA, 2018c).

- Grenada (autonomous country, member of British Commonwealth) has an estimated population of slightly more than 112,000 (2018) and its main agricultural activities are bananas, cocoa, nutmeg, mace, soursop, citrus, avocados, root crops, maize, vegetables; fishing also takes place (CIA, 2018f).

- Montserrat (UK) has an estimated population of slightly more than 5,000 (2018), with limited agricultural activities; the main products are cabbages, carrots, cucumbers, tomatoes, onions and peppers, and some livestock production takes place (CIA, 2018g).

- Saba (Caribbean Netherlands) has an estimated population of about 1,900 (Wikipedia, $2019 \mathrm{~b}$ ) and produces some vegetables and fruit.

- Sint Eustatius (Caribbean Netherlands) has an estimated population of about 4,000 
(Wikipedia, 2019c) and also produces some vegetables and fruit.

- Sint Maarten (Netherlands) has a population of slightly more than 42,600 (Wikipedia, 2019d) and agriculture is an unimportant economic activity, with sugar as an export product.

- St Kitts and Nevis (autonomous country, member of British Commonwealth) have an estimated population of slightly more than 53,000 (2018) with very limited agricultural activities; products are rice, yams, vegetables, bananas, and there is also fishing (CIA, 2018h).

- St Lucia (UK) has an estimated population of slightly more than 165,000 (2018) with some agricultural activities, including production of bananas, coconuts, vegetables, citrus, root crops and cocoa (CIA, 2018i).

- St Vincent and the Grenadines (autonomous country, member of British Commonwealth) have an estimated population of almost 102,000 (2018), with some agricultural activities, including production of bananas, coconuts, sweet potatoes, spices; there is some livestock production (cattle, sheep, pigs, goats) and also fishing (CIA, 2018j).

- The Virgin Islands (UK and USA) have an estimated population of almost 107,000 (2018) and have few agricultural activities; main products are fruit, vegetables, sorghum and some cattle (CIA, 2018k).

\subsection{History of Biological Control in the Remaining Caribbean Islands}

Most of the information in this section originates from Cock (1985). As the review by Cock (1985) covers the period up to 1980, we will not split the information in two periods (1880-1969 and 1970-1999) as done in the other chapters. Section 27.3 (Current situation of biological control in the remaining Caribbean islands) will include developments since 1980.

\subsubsection{Biological control of pests of citrus}

On the islands discussed in this chapter, citrus production is small and mainly for local consumption. Still, several attempts to develop biocontrol took place in citrus and these are summarized below.

\section{Citrus blackfly}

BAHAMAS. Citrus blackfly Aleurocanthus woglumi Ashby occurred in the Bahamas prior to 1916. Releases of Eretmocerus serius Silv. obtained from Cuba in 1931 resulted in establishment, but control was insufficient, though in 1947 citrus blackfly seemed to be well controlled by this parasitoid. The predatory coccinellid Catana clauseni Chapin was also obtained from Cuba and released in 1936, but did not establish. In 1972, as a result of new blackfly outbreaks, Encarsia opulenta (Silv.) was obtained from Barbados and resulted in sufficient control in 1973.

CAYMAN ISLANDS. E. serius from Jamaica was released in the 1940s and 1950s on Grand Cayman, and more releases of E. serius, apparently also containing E. opulenta, were made in 1966. In 1970, only E. opulenta was found on the island.

\section{Various whitefly species}

BAHAMAs. Three aphelinids, Encarsia meritoria Gah., E. sp.nr. variegata How. and Coccophagus aleurodici Gir., and the coccinellid Nephaspis amnicola Wingo were obtained in 1961-1962 from Trinidad and Tobago and released in the Bahamas for whitefly control in citrus and other crops.

ST VINCENT. Miscellaneous coccinellids from Trinidad and Tobago were sent to St Vincent in 1951 for control of whitefly and coccids.

COTTONY CUSHION SCALE. Cottony cushion scale Icerya purchasi Mask. is present on many islands in the Caribbean region and releases have been made with the coccinellid predator Rodolia cardinalis (Muls.) in most of the infested islands.

ANTIGUA. Releases of $R$. cardinalis were made in 1966, 1970 and 1973 with individuals from St Kitts and Montserrat.

BAHAMAS. R. cardinalis releases were made from Puerto Rico in 1934, which resulted in good control. 
CAYMAN ISLANDS. R. cardinalis was found in 1970 on Grand Cayman without records of introductions. Additional releases were made on Grand Cayman and predators were also released on Little Cayman with material from Barbados. Good control results were obtained.

MONTSERRAT. Several $R$. cardinalis releases were made on Montserrat. In 1964-1965 predators from Bermuda were released and in 1966 predators from St Kitts were reared and released. In late 1966 excellent control had been achieved.

ST KITTS. In 1966, R. cardinalis was introduced from Barbados into St Kitts and established. Field-collected and cage-reared individuals were released in heavily infested sites, resulting in good control. Due to flare-ups of the pest, the tachinid Cryptochetum iceryae (Will.) was introduced from California.

\section{Citrus mealybug}

Citrus mealybug Planococcus citri (Risso) is a minor pest of citrus in the Caribbean.

BAHAMAS. A first attempt to introduce Cryptolaemus montrouzieri Mulsant from Florida into the Bahamas in 1932 was not successful. In 1968 it was introduced again against the sugarcane mealybug Sacchariccoccus sacchari (Ckll.) and recovered from sugarcane as well as from citrus infested with $P$. citri.

GRENADA. The coccinellid Cryptognatha affinis Crotch was introduced from Trinidad and Tobago into Grenada for control of P. citri.

MONTSERRAT. CABI UK sent C. montrouzieri to Montserrat in 1935 for control of P. citri, but it is unknown whether it established.

\section{Citrus weevils}

Citrus weevils of the genus Diaprepes damage roots and seedlings of citrus trees.

ST LUCIA. Tetrastichus gala W1k. was sent from Dominica to St Lucia in 1938 for citrus weevil control, but is it is not known if it established.

\section{Fruit flies}

Anastrepha spp. fruit flies may cause serious damage to citrus and other fruit.

ST KITTS. Shipments of Biosteres longicaudatus (Ashmead) and Aceratoneuromyia indica (Silvestri) were made in 1966 to St Kitts from Mexico via Trinidad and Tobago. Also in 1966, Pachycrepoideus vindemmiae (Rondani) was introduced from Trinidad and Tobago to St Kitts. In November 1966 new shipments containing Doryctobracon cereus (Szépligeti), A. indica, B. longicaudatus and $P$. vindemmiae were received from Mexico and Trinidad and Tobago. In 1970, Opius spp. and $P$. vindemmiae were sent from Trinidad and Tobago. Next, B. longicaudatus was introduced from Costa Rica via Trinidad and Tobago in 1973, and in 1974 from Florida. No recoveries were made.

\subsubsection{Biological control of pests of coconuts}

Coconuts are extensively grown on plantation scale, as well as in smallholdings and gardens in the Caribbean.

\section{Coconut whitefly}

ST VINCENT. The coconut whitefly Aleurodicus cocois (Curt.) occurs on several Caribbean islands. One of its natural enemies, Encarsiella noyesi Hayat, was first found on Trinidad and Tobago, but was also collected in other Caribbean islands, including Antigua and Grenada, and Central and South America (Boughton et al., 2015). The parasitoid has been successfully used for control of the coconut whitefly on various Caribbean islands (see country-specific chapters), but introduction of E. noyesi to St Vincent in 1950 did not result in recovery (Cock, 1985).

\section{Coconut mealybug}

ST KITTS. Several native natural enemies of the coconut mealybug Nipaecoccus nipae Mask. were found on St Kitts, including the predators Leucopis bella Loew, an undetermined cecidomyiid, Chrysopa sp., Scymnus sp. and the parasitoid Allotropa sp. Cryptolaemus montrouzieri was introduced 
from India via Trinidad and Tobago between 1971 and 1973, resulting in establishment and a strong reduction of infestations. In 1971, the coccinellid predator Hyperaspis jucunda (Muls.) was introduced from Trinidad and Tobago, followed by shipments of the parasitoid Pseudaphycus utilis Timberlake in 1972, also from Trinidad and Tobago; there are no reports of establishment of the predator and the parasitoid.

\section{Coconut scale}

Many introductions of coccinellids, often from colonies started in Trinidad and Tobago, were made into Caribbean islands for the control of the coconut scale Aspidiotus destructor Sign. between 1937 and 1973.

ANTIGUA. After a coconut scale outbreak in 1937, Cryptognatha nodiceps Marshall was introduced from Trinidad and Tobago, but there are no reports of establishment.

BAHAMAS. In the Bahamas, coconut scale is attacked by the parasitoids Aspidiotiphagus sp. and Encarsia sp. and the predators Chilocorus cacti L. and Diomus sp., but control is insufficient. Cryptognatha, Pseudoazya trinitatis (Marshall) and 'Pentilia spp.' were shipped from Trinidad and Tobago in 1961-1962, but did not establish.

CAYMAN ISLANDS. Coccinellids, including Chnoodes sp., C. nodiceps, and P. trinitatis, were introduced from Trinidad and Tobago in 1949, followed in 1970 by releases of $C$. nodiceps and $P$. trinitatis from Trinidad and Tobago, and Coccidophilus cariba Gordon (as C. citricola Breth.) from Nevis.

GRENADA. Many species of coccinellids, including Chnoodes sp., C. nodiceps, P. trinitatis, Azya orbigera Muls., Chilocorus bipustulatus L., Exochonus bisbinotatus Gorham, Exoplectra dubia Crotch, Lotis neglecta Muls., Lotis nigerimma Csy., Pentilia spp., Scymnus sp., Telsimia nitida Chapin, Zenoria emarginata Gordon and Rhyzobius pulchellus Montrouzier, were released between 1947 and 1970 on Grenada, mainly originating from colonies from Trinidad and Tobago. Before the first releases were made, C. cacti and a Scymnus sp. were found associated with the coconut scale in Grenada. Few, if any, of the released species were recorded during surveys.
MONTSERRAT. Rhyzobius pulchellus was introduced into Montserrat from Trinidad and Tobago in 1971, but establishment was not reported.

ST KITTS AND NEVIS. The coccinellids $P$. trinitatis, C. cacti and Coccidophilus cariba Gordon and the parasitoid Aphytis sp. were found present in 1966. In 1970, when scale damage was very serious, C. nodiceps was introduced from Trinidad and Tobago, resulting in a good degree of control.

ST LUCIA. After heavy coconut scale attacks, the coccinellids C. nodiceps, Cryptognatha simillima Sicardi, P. trinitatis, Pentilia egena Muls. and Cryptognatha flaviceps Crotch were introduced from Trinidad and Tobago in 1938-1939. In 1950, only P. trinitatis was found. In 1971, R. pulchellus was introduced from Trinidad and Tobago.

ST VINCENT. On this island only $C$. cacti and an Azya sp. seemed to be present on coconut before 1950. In 1951, Chnoodes sp., Cladis nitidula F., C. similima and C. nodiceps, Lioscymnus diversipes Champ., L. neglecta, L. nigerimma, Pentilla spp., P. trinitatis, R. lophanthae and Scymnus sp. were introduced, mainly from Trinidad and Tobago. Later, R. pulchellus was introduced. There are no reports of establishment.

\subsubsection{Biological control of pests of other tree crops and ornamentals}

\section{Orthezia scales}

GRENADA. Orthezia spp. scales sometimes create problems on limes and other citrus fruit on Grenada and seem to have only Melaleucopis simmondsi Sabrosky as a native natural enemy. Miscellaneous coccinellids from Trinidad and Tobago were released in 1952, and in 1953 Rhinoleucophenga sp. and Hyperaspis donzeli Mulsant were introduced. None of the species was recovered later in 1953.

\section{Miscellaneous mealybugs}

MONTSERRAT. Cryptolaemus montrouzieri was sent from Trinidad and Tobago for release against Puto barberi (Ckll.) on citrus. There are no reports of recovery. 


\section{Miscellaneous scale insects}

BAHAMAS. The coccinellids A. orbigera and Cryptolaemus affinis Crotch were sent from Trinidad and Tobago in 1961 for control of Pulvinaria psidii Mask. on guava. Before they were released, the pest population had declined, so the coccinellids had little chance of establishment.

\section{Cocoa thrips}

The cocoa thrips Selenothrips rubrocinctus (Giard) is a pest of cocoa and cashew in the Caribbean. However, outbreaks subside when shade and windbreaks were provided as a cultural practice when producing cocoa.

GRENADA. A hyphomycete fungus Beauveria globulifer (Speg.) Pic., obtained from St Vincent, killed many thrips when sprayed on cocoa plants, but it provided control only when the humidity was high. The parasitoid Goetheana parvipennis (Gahan) was introduced from Trinidad and Tobago in 1937, but was not recovered.

\section{Banana weevil}

Bananas and plantains are grown for domestic consumption throughout the Caribbean, but Grenada, St Lucia and St Vincent are also exporting bananas. The banana weevil Cosmopolites sordidus (Germ.) is the most important pest and the only one against which biocontrol was attempted with the predatory beetles Plaesius javanus Erichs., Dactylosternum hydrophiloides (Macleay) and D. abdominale (F.) from South-east Asia, and Hololepta (= Leionota) quadridentate (F.), a native of Trinidad and Tobago that has adapted to feeding on the banana weevil.

GRENADA. In 1949 and 1951, P. javanus and H. quadridentata from Trinidad and Tobago were released in piles of rotting banana stems. The two species were not recovered in 1951 and later.

ST LUCIA. In the 1950s, C. sordidus caused serious damage to bananas and plantains. During 1950-1954, H. quadridentata, P. javanus and Dactylosternum sp. (presumably D. subdepressum Lap.) from Trinidad and Tobago were released. In 1971, a Dactylosternum sp. was collected which might have been native, but no histerids were recovered.
ST VINCENT. In 1951, P. javanus sent from Jamaica via Trinidad and Tobago were released by mistake in sugarcane fields. Although there is no record of the introduction of H. quadridentata in St Vincent, an adult was obtained from a banana stump and several from felled palm trunks attacked by the curculionid Rhynchophorus palmarum L. in 1970.

\subsubsection{Biological control of pests of cotton}

West Indian sea island cotton, a cultivar of Gossypium barbadense L, produces the highest quality lint of any commercially grown cotton. Prior to the 1940s, sea island cotton was grown extensively in many islands in the Caribbean, but its importance declined and little biocontrol of its pests was attempted. However, due to high demand for this type of cotton in the 1970s, interest in biocontrol of its pests also increased.

\section{Cotton stainers}

Cotton is attacked by cotton stainers, Dysdercus spp., wherever it is grown. Dysdercus andreae (L.) occurs in Antigua, Montserrat and Nevis, while D. fulvoniger Deg. ssp. discolor Wlk. occurs in St Vincent and Montserrat. Cotton stainers are generally minor pests in the Caribbean, but they can build up large populations where alternative host plants are present. The tachinids Hyalomyia chilensis Macq. and Acaulona peruviana Tns. were released to supplement the native A. erythropyga Sabrosky, but did not become established.

\section{Green stink bug}

The green stink bug Nezara viridula (L.) is the most serious pest on cotton in Antigua and Montserrat.

ANTIGUA. In 1949, Trichopoda pennipes (F.) from Florida was released, with no evidence of establishment. In 1955, Trichopoda pilipes (F.) reared from $N$. viridula from Montserrat was released. In 1961-1962 shipments of Anastatus spp. originating from Pakistan and mass produced in Trinidad and Tobago were released. In 1963, Xenoencyrtus niger Riek from Hawaii and reared in Trinidad and Tobago was released. No recoveries were made of any of these species. 
MONTSERRAT. $\quad N$. viridula is common in Montserrat. This may explain why the parasitoid T. pilipes is much more common in Montserrat than in other Caribbean islands. Among the other parasitoids in the region are the widely distributed scelionid Trissolcus basalis (Woll.) and the encyrtids Ooencyrtus submetallicus (How.) and O. trinidadensis J.C.Crawford. Although these parasitoids provide some level of control elsewhere, N. viridula is still a sufficiently serious pest of several crops to continue attempts at biocontrol. In 1961-1962 shipments of Anastatus spp. originating from Pakistan and mass produced in Trinidad and Tobago were released. In 1966, Trissolcus mitsukurii (Ashm.) from Japan and mass reared in Trinidad and Tobago was released. No recoveries of Anastatus and T. mitsukurii were made.

ST KITTS. In 1961-1962 Anastatus spp. and in 1966 T. mitsukurii were released. No recoveries of Anastatus and T. mitsukurii were made.

ST VINCENT. In 1961-1962, Anastatus spp. were released, but no recoveries were made.

\section{Pink bollworm}

Native Caribbean parasitoids of pink bollworm Pectinophora gossypiella (Saund.) include a braconid Bracon hebetor Say, the chalcidids Spilochalcis torvina (Cress.) and Brachymeria sp., and the bethylid Perisierola nigrifemur (Ashm.), but their combined parasitism is negligible.

ANTIGUA, MONTSERRAT, ST KITTS AND ST VINCENT. Apanteles sp. ? angeleti, Bracon greeni Ashmead and Brachycoryphus nursei (Cam.) were sent to Trinidad and Tobago from India, cultured and introduced into the islands in 1962-1963, but no recoveries were found in 1964.

\section{Cotton leafworm}

Cotton leafworm Alabama argillacea $(\mathrm{Hb}$.) is attacked by the local parasitoids Trichogramma sp., Apanteles sp., Brachymeria sp., Winthemia spp. and Sarcophaga sp. Attempts at biocontrol have centred on the importation or manipulation of predatory vespid wasps, Polistes spp.

ST VINCENT. The Jack Spaniard wasp of St Vincent, Polistes cinctus cinctus Lepeletier, is an effective predator of the cotton leafworm. Initially it was assumed that the St Vincent race of this wasp was a more effective predator strain than strains on other islands and it was introduced into several islands. Later it was argued that the better control obtained on St Vincent results from the constant supply of food for $P$. c. cinctus in the form of the arrowroot leaf roller Calpodes ethlius (Stoll). If this view is correct, then the introductions discussed below are unlikely to lead to improved control of A. argillacea. P. c. cinctus has been encouraged in St Vincent by the erection of shelters near the cotton fields under which it can nest, which is an example of conservation biocontrol.

ANTIGUA. In 1910 and subsequently, attempts were made to establish Polistes cinctus barbadensis Richards from Barbados and P. c. cinctus from St Vincent, but they failed to establish.

GRENADA. P. $c$. cinctus was plentiful at one time but became scarce and fresh stock was introduced from St Vincent. In 1919, it was reported that the wasp was almost extinct and later it was no longer found.

MONTSERRAT. P. c. cinctus was introduced from St Vincent in 1910, although this subspecies was already present. In 1918, it was reported to be controlling the pest in the area where it was first established, but later control appeared insufficient. The species was found well established during surveys in 1961, 1966 and 1973.

ST KITTS. An unsuccessful attempt was made to introduce P. c. cinctus into St Kitts from St Vincent in 1919. However, in 1978 this subspecies was recorded on the island.

ST LUCIA. P. $c$. cinctus was introduced in 1916 from St Vincent, reported as established in some areas in 1934 and recovered in 1970.

\subsubsection{Biological control of pests of cruciferous crops}

Cabbage is an important crop in the region, while cauliflower and Chinese cabbage are also 
grown. Main pests of these crops in the Caribbean are all Lepidoptera, with cabbage budworm Hellula phidilealis (Wlk.) and the diamondback moth Plutella xylostella (L.) as the two most important. On some islands the cabbage butterfly Ascia monuste (L.) and the cabbage loopers Trichoplusia ni (Hb.) (= Plusia brassicae Ril.) and Chrysodeixis includens (Wlk.) are also important.

\section{Diamondback moth}

Diamondback moth P. xylostella is attacked by a variety of local parasitoids, including braconids Apanteles sp. and Apanteles (Rhygoplitis) aciculatus (Ashm.); trichogrammatid egg parasitoids Trichogramma sp. and Trichogramma brasiliensis (Ashm.); a facultative hyperparasitic eulophid Tetrastichus sokolowskii Kurd.; and a preferentially hyperparasitic chalcidid Spilochalcis hirtifemora (Ashm.). The local parasitoids failed to control diamondback moth, particularly when pesticides were regularly applied. Apanteles (Cotesia) plutellae Kurd was obtained from India in 1970, Diadegma eucerophaga Horstmann and A. plutellae from the Netherlands in 1971, and D. varuna Gupta and Diadromus collaris (Grav.) from India in 1972. Both Diadegma spp. failed to develop more than one generation in the laboratory in Trinidad and Tobago, but the two strains of $A$. plutellae and $D$. collaris were mass produced and distributed throughout the area, including Antigua, Grenada, Montserrat, St Kitts and Nevis, St Lucia and St Vincent. It seems, however, that the parasitoids hardly suppressed diamondback moth.

ANTIGUA. The Indian strain of A. plutellae was introduced in 1970-1972, the Dutch strain in 1972 and D. collaris in 1972. A. plutellae was recovered in 1971, indicating at least temporary establishment.

GRENADA. The Indian strain of A. plutellae was introduced in 1970-1972, the Dutch strain in 1972 and D. collaris in 1972. No recovery data are available.

MONTSERRAT. A. plutellae was released in 1971 and recovered in 1971 and 1973, suggesting that it had established.
ST KITTS AND NEVIS. A. plutellae was recovered from both St Kitts and Nevis in 1973 following releases of the Indian and Dutch strain in 19701972 , but $D$. collaris released in $1972-1973$ was not recovered.

ST LUCIA. A. plutellae was recovered in 1973 at its release site of the previous years, but $D$. collaris released in 1972 was not recovered.

ST VINCENT. The Indian strain of A. plutellae was introduced in 1970-1972, the Dutch strain in 1972 and D. collaris in 1972. Recovery surveys made in 1972 did not result in finding any of the two parasitoids.

\section{Cabbage butterfly}

Cabbage butterfly $A$. monuste is causing damage to crucifers in the Caribbean (for more details see Chapter 3: Barbados).

ST LUCIA. A single consignment of Pteromalus puparum L. was sent from Barbados and released in 1950, but no recoveries have been made.

\subsubsection{Biological control of pests of sugarcane}

In most of the Caribbean, sugarcane was the dominant agricultural crop during the 19th century and first half of the 20th century. Although production decreased and was no longer continued on some of the islands, it is still the most widely grown crop in the region as a whole.

\section{West Indian cane fly}

West Indian cane fly Saccharosydne saccharivora (Westw.) has a well developed natural enemy complex in the Caribbean, but irregular outbreaks occur leading to attempts to establish new natural enemies.

BAHAMAS. West Indian cane fly was widespread but of minor importance. Small releases were made of Anagrus flaveolus Waterhouse from Jamaica and Trinidad and Tobago in 1968 and from Barbados in 1972, but the parasitoid was not recovered. 


\section{Sugarcane froghopper}

GRENADA. Sugarcane froghopper Aeneolamia spp. occurs as pests of sugarcane on Grenada, where Metarhizium anisopliae (Metschnikoff) Sorokin was found to infect Aeneolamia varia var. saccharina (Dist.), resulting in its control.

\section{Yellow sugarcane aphid}

The yellow sugarcane aphid Sipha flava (Forbes) occurs throughout the Caribbean and is an occasional pest of various Gramineae.

BAHAMAS. Coccinella septempunctata L. obtained from Pakistan was released in 1968 to supplement local natural enemies, but no recoveries were made.

\section{Sugarcane mealybugs}

The sugarcane mealybugs Saccharicoccus sacchari (Ckll.). and Dysmicoccus boninsis (Kuway.) occur wherever sugarcane is grown.

BAHAMAS. Since the natural enemies already present did not provide sufficient control, coccinellids Nephus sp., Hyperaspis sp. and C. montrouzieri were imported from India in 1968, and additional Hyperaspis trilineata Muls. obtained from Barbados in 1968-1969 were liberated. Hyperaspis trilineata was recovered several times during 1968 and 1969, but did not become abundant. C. montrouzieri became established and spread rapidly, and to prevents its elimination when cane fields were burnt prior to harvesting, coccinellids were collected and transferred to other fields.

ST KITTS. Hyperaspis trilineata adults were imported from Barbados in 1958. In 1966 recoveries were made and they were widespread in 1967, contributing to $S$. sacchari control. The encyrtid Anagyrus saccharicola Timb. obtained from East Africa was introduced via Trinidad and Tobago to St Kitts in 1971 and established, according to recoveries made in 1975 and 1978.

\section{White grub larvae of beetles}

ANTIGUA. The brown hard-back beetles Phyllophaga antiguae (Arr.) and Phyllophaga sp. caused severe damage to sugarcane prior to 1915. Planting of Cordia curassavica (Jacq.) R. \& S. (= interrupta), which provide nectar to adults of the native tiphiid, Tiphia parallela F. Sm., a well known parasitoid of Phyllophaga spp., resulted in a reduction of beetle populations. This can be considered as an example of conservation biocontrol.

\section{Sugarcane borers}

Sugarcane borers, Diatraea spp., are the most widespread and in many places the most important pests of sugarcane in the Caribbean. Diatraea saccharalis (F.) is the most prominent of these and occurs throughout the region except the Bahamas, where it is replaced by $D$. lineolata (Wlk.). Two other species, Diatraea centrella (Moschler) (= canella Hamps.) and D. impersonatella (Wlk.), occur on some of the islands discussed in this chapter. Biocontrol of Diatraea spp. proceeded in three phases. During the first half of the 20th century, native tachinid Diatraea parasitoids with limited ranges within the Neotropical Region were redistributed, often leading to a degree of control. From 1929 to 1959 , extensive trials were made with inundative releases of Trichogramma spp., principally in Barbados and Guyana. From 1950, when CABI set up its laboratory in Trinidad and Tobago, a number of exotic stem borer parasitoids were imported from Africa and Asia, and one of these, Cotesia flavipes (Cam.), proved particularly successful. Tables 11, 12 and 13 in Cock (1985) summarized the many introductions of natural enemies of sugarcane borers in the Caribbean.

ANTIGUA. Ipobracon grenadensis Ashm. and Agathis stigmatera Cress. from Guyana were introduced in 1926 but did not establish. In 1932 the tachinid parasitoid Lixophaga diatraeae (Townsend) was imported from Cuba, bred in the laboratory, released in several places, established, and sugarcane damage due to $D$. saccharalis decreased. However, in 1936, D. saccharalis damage increased again and additional releases were made with $L$. diatraeae from St Kitts. The parasitoid established but provided insufficient control, so inoculative seasonal releases were made annually from 1937 to the 1960 s, when commercial sugarcane production ceased. Paratheresia claripalpis Wulp. from Trinidad and Tobago and 
Lydella minense (Townsend) from Guyana were released in 1937-1938, and small releases of C. flavipes were made in 1970.

BAHAMAS. When commercial large-scale plantings of sugarcane started in 1965, damage during this period was caused by D. lineolate. In 1967 it was confirmed that D. centrella was present and caused serious damage. Chemical control failed and 20 species of hymenopteran parasitoids of Diatraea spp. and of allied stem borers were introduced in an extensive biocontrol programme during 1968-1970 (Table 14 in Cock, 1985). Also the tachinids Jaynesleskia jaynesi Townsend and Palpozenillia diatraeae Townsend were released in this period. None of the hymenopteran or tachinid species established. The sugarcane industry was closed down in 1970.

GRENADA. During 1950-1954, L. minense, $P$. claripalpis and $L$. diatraeae were shipped from Trinidad and Tobago and released. Telenomus alecto Crawford, obtained from Barbados and bred in Trinidad and Tobago, was also shipped. Other releases have been made since 1961, but none of the introduced parasitoids established.

MONTSERRAT. Lixophaga diatraeae was introduced from St Kitts in March 1935 for control of D. saccharalis, but there are no reports of recoveries. Later, other parasitoid species were introduced (Table 14 in Cock, 1985). During a recovery survey in 1965 , only $L$. diatraeae was found, but no recoveries of this species were made during a survey in 1966 .

ST KITTS AND NEVIS. D. saccharalis is the only borer present and was, prior to parasitoid introductions, attacked by Trichogramma exiguum Pinto \& Platner, Agathis stigmatera (Cresson) and the fungus Cordyceps barberi Giard, but control was insufficient. From 1932 to 1934 L. diatraeae was introduced and spread over the island. Sugarcane borer injury decreased to values below the economic threshold and remained at that level. From 1970 to 1973 L. minense, C. flavipes, Pediobius furvus (Gah.) and Apanteles sesamiae Cam. were introduced, but only C. flavipes established. Borer damage appeared to have increased in 1978 , supposedly due to use of new sugarcane varieties, pre-harvest burning and drought. In 1982 the Caribbean Agricultural Research and Development Institute (CARDI) started the release of Allorhogas sp..

ST LUCIA. In the 1930 s infestation by D. saccharalis and D. centrella was high. In 1933, L. diatraeae were obtained from Antigua. Parasitoids were recovered from $D$. saccharalis, but not from D. centrella. The parasitoid did not sufficiently control D. saccharalis. Lydella minense was obtained from Guyana in 1934, and establishment and spread occurred rapidly. Borer damage caused by $D$. saccharalis decreased to below the economic threshold, but for $D$. centrella the reduction was less spectacular.

ST VINCENT. D. saccharalis predominates in plant cane and D. centrella usually in ratoons. Native parasitoids of borers found on the island were T. exiguum, T. alecto and A. stigmatera. Between 1940 and 1961 several parasitoids were introduced (Table 14 in Cock, 1985), but no recoveries were made. Cotesia flavipes obtained from Barbados was released in 1978 and 1982, and recoveries were made in 1979 and 1980.

\subsubsection{Biological control of pests of other vegetable and field crops}

\section{Phytophagous snails}

BAHAMAS. Phytophagous snails, especially Zachrisia auricoma (Ferussac) and Bulimulus sepulcralalis (Poey), occur on these islands. In 1961-1962 small shipments of the predacious snail Euglandina rosea (Ferussac), originating from East Africa, were obtained from Bermuda and liberated for control of Z. auricoma and B. sepulcralis; it was recovered in 1970. Gonaxis quadrilateralis (Preston) (origin East Africa) individuals sent to Trinidad and Tobago from Hawaii in 1968 were forwarded to the Bahamas for liberation. There are no records of recoveries.

\section{Pigeon pea pod borers}

Of the various species of pigeon pea pod borers occurring in the Caribbean, Ancylostomia siercorea (Zell.) is the most serious pest. 
BAHAMAS. Thousands of various species of parasitoids of A. stercorea were sent from Trinidad and Tobago (Table 19 in Cock, 1985) and liberated into heavily attacked pigeon pea sites from 1952 to 1970. Although conditions for establishment seemed ideal, not a single recovery was made.

\section{Arrowroot leaf roller}

The arrowroot leaf roller Calpodes ethlius (Stoll) is a pest of arrowroot Maranta arundinacea L., which is grown for its fine-grained starch. St Vincent is the principal world producer, although it has also been grown in Barbados, Bermuda, Dominica, Jamaica and St Lucia, and small amounts are still grown in Antigua and Montserrat.

ST VINCENT. Here, the principal egg parasitoid of the leaf roller is a dark 'race' of Trichogramma 'minutum Riley', which might be the same race found parasitizing $C$. ethlius over a wide area in the Americas. Also, an eulophid, Ardalus scutellatus (How.), was recorded from St Vincent. Other parasitoid records from St Vincent include a chalcidid, two tachinids and two sarcophagids. In 1951-1952, Ooencyrtus sp., Apanteles talidicica Wlkn. and A. scutellatus were introduced from Trinidad and Tobago. Ooencyrtus established well. The chief predators of C. ethlius in St Vincent are 'Jack Spaniard' wasps, Anolis lizards and birds. The wasp P. cinctus cinctus is very active wherever there is a heavy leaf roller attack. Some farmers erected roofed shelters on wooden stands scattered through the fields to afford nesting sites for the wasps, thus encouraging the growth of the predator population, an example of conservation biocontrol.

\section{Armyworms}

In the Caribbean region, armyworms of five species of Spodoptera and two species of Heliothis are of economic importance: $S$. frugiperda (J.E. Smith), S. latifascia (Wlk.), S. dolichos (F.), S. eridania (Cram.), S. sunia (Gn.), H. zea (Boddie) and H. virescens (F.). In addition $S$. exigua (Hb.) is extending its range and will probably spread through the Caribbean. The larvae of all these species feed on a variety of crops and are general defoliators.
S. frugiperda and H. zea are particularly associated with maize, $S$. eridania with cabbage and tomato, $H$. virescens with pigeon pea, and $S$. frugiperda, S. latifascia, S. eridania and $S$. sunia with cotton. Other crops that are attacked include asparagus, beans, beet, carrot, cauliflower, aubergine, okra, onion, peppers, potato, pumpkin, sugarcane, sweet potato and tobacco. Spodoptera ornithogalli (Gn.) does not occur in the region, except in Antigua. Many species of parasitoids of armyworms were received by CABI in Trinidad and Tobago from Asia, Europe and North and South America from 1970 to 1980 and several of these species were introduced into other Caribbean islands. After 1980, biocontrol attempts were made by CARDI.

ANTIGUA, BAHAMAS, GRENADA, ST KITTS, ST LUCIA, ST VINCENT. Several species of parasitoids have been introduced to the islands (Tables 24 and 25 in Cock, 1985), but only Telenomus remus Nixon established on Antigua, Dominica and St Vincent and no recoveries of other species have been made.

MONTSERRAT. T. remus was released on Montserrat in 1973 by CABI and later by CARDI, and established.

\subsubsection{Biological control of forestry pests}

\section{Mahogany shoot borer}

The mahogany shoot borer Hypsipyla grandella (ZeM.) is a pest of mahogany (Swietenia macrophylla G. King and S. mahagoni Jacq.), cedar (Cedrela odorata L.) and crappo (Carapa guianensis Aubl.), which are forest trees of commercial value in the Caribbean.

GRENADA, ST KITTS, ST LUCIA AND ST VINCENT. Surveys undertaken by CABI revealed several natural enemies on these islands (five braconids, two ichneumonids, two trichogrammatids, two tachinids and a mermithid), but these did not sufficiently control H. grandella. Several species of parasitoids were imported from Asia from 1968 to 1982 (Cock, 1985) and released. During surveys in 1970-1972, none of the released parasitoids was recovered. 


\subsubsection{Biological control of pests of humans and domestic animals}

\section{House and stable flies}

House flies (Musca spp.) and stable flies (Stomoxys spp.) breed in large numbers in the accumulated excrement found in stables and poultry pens.

GRENADA. In 1951, a shipment of Pachylister chinensis Quensel, a histerid native to Malaysia and Indonesia, was sent from Trinidad and Tobago for release.

ST KITTS. Muscidifurax uniraptor Kogan \& Legner (1966) and Pachycrepoideus vindemmiae Rond. (1966 and 1970) originating from California were released against house flies and fruit flies (Anastrepha spp.), but no recoveries were made.

ST VINCENT. Pachylister chinensis from Trinidad and Tobago was released in 1951. No records about establishment are available.

\section{Mosquitoes vectoring human diseases}

SINT MAARTEN. Gerberg and Visser (1978) reported: 'A preliminary field trial on the Caribbean island of St Maarten demonstrated the feasibility of using a predator mosquito larva, Toxorhynchites brevipalpis Theob. as a biocontrol agent for Aedes aegypti L. Sixteen days after the introduction of T. brevipalpis eggs into A. aegypti breeding containers, all of the 21 houses sampled no longer had A. aegypti breeding.' The authors concluded that the predator could be mass reared in sufficient quantities, predator eggs could be transported by air and would hatch into larvae in the climate of St Maarten. They anticipated that flooding St Maarten with predator eggs at 4-week intervals might well suppress and possibly eradicate $A$. aegypti.

\subsubsection{Introduction of vertebrate natural enemies into the Caribbean}

Several vertebrates have been introduced into the Caribbean, but this is no longer recommended, due to their wide food range, resulting in negative non-target effects such as preying on beneficial and economically important organisms, as well as on other valued species. Species that were not introduced for pest or weed control but that have resulted in non-target effects were discussed in Cock (1985).

\section{Giant toad}

The first introduction of the giant toad Bufo marinus (L.) was into Barbados from Guyana in about 1830 to control white grubs in sugarcane (see Chapter 3: Barbados). The toad was then moved from Barbados to most of the Caribbean islands. According to Cock (1985), the toads do consume large numbers of insects in cane, and although this doubtless includes many beneficial insects, on balance they are probably beneficial.

\section{Small Indian mongoose}

The small Indian mongoose Herpestes auropunctatus (Hodgson) was introduced into Jamaica in 1872 from India to control rats. It had spread to many of the other Caribbean islands by the end of the century. It established on Antigua, Grenada, St Kitts and Nevis, St Lucia, St Vincent and some of the Virgin Islands, among others. Early reports suggested a substantial reduction in rats and their damage, but mongoose quickly showed negative non-target effects. Lizards of Ameiva spp. occur widely in the Caribbean and are considered beneficial insect predators. Wherever the mongoose became established, these lizards became rare or extinct. The effects on groundnesting birds have been similar. There is little evidence with regard to the effect on snakes. Mongooses are also widely recognized as pests of poultry and cause considerable concern as vectors of rabies. On the whole, the introduction of the mongoose has been harmful.

\subsubsection{Biological control of weeds}

\section{Prickly pear}

Prickly pear (Opuntia spp.) has been controlled in several world regions after introduction of cochineal insects of Dactylopius spp. originating from North America and a pyralid Cactoblastis cactorum (Berg) originating from Argentina. In the Caribbean, C. cactorum was introduced first to Nevis and then released in Antigua, the Cayman islands and Montserrat, and spread naturally to 
other islands in the Caribbean, including the Bahamas.

ANTIGUA. C. cactorum was brought from Nevis in 1960 and successfully established on Opuntia triacantha (Willd.) Sweet, which it controlled effectively.

CAYMAN ISLANDS. C. cactorum was introduced into the Cayman Islands from Nevis and Antigua in 1970 and became well established on Opuntia dillenii (Ker-Gawler) Haworth .

MONTSERRAT. O. triacantha was successfully controlled after the introduction of $C$. cactorum in 1960 from Nevis.

ST KITTS AND NEVIS. Three species, O. dillenii, Opuntia lindheimeri Engelmann and O. triacantha, caused most problems in Nevis. Of these, O. triacantha was the most serious, as it displaced pasture grass and the spines caused injury to livestock. C. cactorum (ex Argentina), Dactylopius opuntiae (Ckll.) (ex USA) and D. austrinis De Lotto (as D. sp. nr. confusus (Ckll.) (ex USA) were introduced into Nevis in 1957. C. cactorum became established and abundant, proving particularly effective against $O$. triacantha. By 1964 O. triacantha was scarce in most areas, the other two species were gone from pastures, but persisted along roadsides, and the programme was considered an outstanding success. Neither species of Dactylopius became established. In 1964, C. cactorum was observed in St Kitts having spread naturally across the 4-mile gap between St Kitts and Nevis

\section{Love vine}

Love vine (Cuscuta spp.) is a considerable nuisance to ornamental garden plants and occasionally becomes a pest of economic plants such as citrus and mango.

BAHAMAS. The dipteran leaf miner Melanagromyza cuscutae Hering and a seed-feeding weevil Smicronyx roridus Mshl. were imported from Pakistan in 1966 and 1968, but no recoveries were made.

\section{Puncture vine}

Puncture vine Tribulus cistoides L. is a palearctic weed that became established in the Caribbean.
Biocontrol is based on the use of the weevils Microlarinus lareynii (Duv.) and M. lypriformis (Woll.). These two weevils were successfully introduced from Italy into California and Hawaii.

ST KITTS AND NEVIS. Puncture vine became established in St Kitts in the 1950s and for several years was considered an attractive ornamental. However, in 1964 when patches of the weed were reported in pasture lands and along the roads, questions about its potential as a weed and methods of control were raised. Attempts of biocontrol in St Kitts were started in 1966; the stem weevil M. lypriformis obtained from Hawaii in November 1966 rapidly became established and within 4 months every stem sampled near the release site was infested. Within a year solid stands of the weed had disappeared from pasture lands and it has been almost completely replaced by grass and other weeds. In 1971 , T. cistoides comprised less than $5 \%$ of the ground cover at sites where in 1966 it covered over $80 \%$. In an attempt to reduce further the reproductive potential of $T$. cistoides, the seed weevil M. lareynii was obtained from California in 1968. Although present in 1969, it was not recovered in October 1969 or March 1971. T. cistoides was first noticed at the airport of Nevis in 1968 and liberations of M. lypriformis were made by placing infested plants from St Kitts near the infestation. Early in 1969, M. lypriformis was well-established and sufficiently controlled puncture vine.

\subsubsection{Remaining Caribbean Islands as source of biological control agents}

Cock (1985) mentioned only a few cases of the Remaining Caribbean Islands being a source for export of natural enemies to countries outside the Caribbean. Many indigenous Caribbean natural enemies from other islands have been sent from Trinidad and Tobago by CABI to countries around the world.

\section{Natural enemies of the green stink bug}

The green stink bug N. viridula is a widespread pest in the Caribbean and export of indigenous parasitoids resulted in some biocontrol success outside the Caribbean area. 
ANTIGUA AND MONTSERRAT. The tachinids T. pilipes collected in Montserrat and T. basalis collected in Antigua and Montserrat were shipped via CABI Trinidad and Tobago to Australia, Hawaii and the USA several times in the period 1952-1979. In Hawaii, T. pilipes established and became common. Trissolcus basalis also became very common, parasitizing over $90 \%$ of the green stink bug eggs. Control below the economic threshold has been achieved in several crops.

\section{Weed biological control agents}

Many aquatic and terrestrial weeds presently found throughout the tropics originated in the Neotropical region and also a number of the most successful examples of biological weed control involve species that originated in this region. In the Caribbean, it is Trinidad and Tobago that have been an important source of weed biocontrol agents (see Chapter 29: Trinidad and Tobago; and Cock, 1985). The Cock (1985) review does not mention any of the Remaining Caribbean Islands as sources of weed biocontrol agents.

\subsubsection{Conclusions about biological control in the Remaining Caribbean Islands up to 1980}

Substantial or complete biocontrol successes in the Remaining Caribbean Islands are summarized in Table 27.1. According to Cock (1985, p. 179):

The projects which achieved these successes can be divided into three types: first, those using known biological control agents which have been consistently successful when used on the same pest problem elsewhere, second, the trial of agents as available from similar hosts,

habitats or crops in ... the 'hit or miss approach', and third, projects based on extensive research and foreign exploration to find suitable control agents.

From the successes listed in Table 27.1, the control of the insect pests $A$. woglumi, A. destructor and I. purchasi and of the weeds Opuntia spp. and Tribulus terrestris L. are examples of the use of biocontrol agents of known effectiveness, while the programmes against $D$. saccharalis were based on extensive research. Other successes obtained in the Caribbean region, such as the control of A. cocois, P. xylostella and S. frugiperda, were the result of introductions based upon minimal research.

Related to releases made in the Caribbean, Cock (1985) discussed the important issue of predictability of success of biocontrol introductions, a topic also addressed in the section on 'Finding, evaluation and utilization of biological control agents' in Chapter 1 of this volume. Cock (1985) mentions that:

\begin{abstract}
It has often been suggested that if a biological control agent has been proven effective in one situation, then it is likely to be effective against the same pest elsewhere. The results of the programme against Diatraea spp. show that this is not always the case, and different parasitoids have been effective on different islands in a totally unpredictable manner. This result provides some justification for the 'hit or miss approach'. Until reliable predictions can be made as to the effectiveness of different types of agents, it is difficult to say that the hit or miss approach is not justified where funds are limited. However, substantial research will be needed to clarify why some agents are effective while others are not, and until such data are available, it is difficult for biological control to develop into a predictive science.
\end{abstract}

Still, when looking at the successes, one may conclude that they were often only obtained after long-term research. For example, in the project of sugarcane borer management in the Caribbean, attempts to develop biocontrol have been going on since the 1930s and more than 50 species of parasitoids have been studied as possible candidates for release (Baker et al., 1992).

\subsection{Current Situation of Biological Control in the Remaining Caribbean Islands}

Many biocontrol programmes were implemented before the 1980s in the Caribbean, but only a few were conducted from 1980 to 1990. From 1990, the region was faced with a number of invasions by exotic pests, including the citrus leaf miner, citrus blackfly, papaya mealybug, giant African snail, coconut whitefly and pink hibiscus mealybug (Kairo et al., 2003a). Invasive species have long been a challenge to Caribbean agriculture, but the problem has been amplified in recent times as the movement of goods and people has 
Table 27.1. Biological control successes achieved with arthropod natural enemies during the period 1880-1980 in the Remaining Caribbean islands (retrieved from Cock, 1985).

\begin{tabular}{|c|c|c|}
\hline Biological control agent & Pest/weed & Remaining Caribbean Island \\
\hline Cotesia flavipes (Cam.) & Diatraea saccharalis (F.) & Antigua \\
\hline Cactoblastis cactorum (Berg) & Opuntia spp. & Many islands \\
\hline Cryptognatha nodiceps (Mshl.) & Aspidiotus destructor Sign. & St Kitts and Nevis \\
\hline $\begin{array}{l}\text { Cryptolaemus montrouzieri } \\
\text { Mulsant }\end{array}$ & Nipaecoccus nipae Mask. & St Kitts \\
\hline $\begin{array}{l}\text { Encarsia opulenta (Silv.), } \\
\text { Eretmocerus serius Silv. }\end{array}$ & Aleurocanthus woglumi Asby & Bahamas, Cayman Islands \\
\hline Lixophaga diatraea Tns. & Diatraea saccharalis (F.) & Antigua, St Kitts \\
\hline Lydella minense Tns. & Diatraea saccharalis (F.) & St Lucia \\
\hline Trichogramma spp. & Diatraea lineolate (WIk.) & Bahamas \\
\hline Metarhizium anisopliae & Aeneolamia spp. & Grenada \\
\hline Microlarinus lypriformis (Woll.) & Tribulus cistoides L. & St Kitts and Nevis \\
\hline Native natural enemy complex & $\begin{array}{l}\text { Saccharosydne saccharivora } \\
\text { (Westw.) }\end{array}$ & Several islands \\
\hline Polistes cinctus cinctus Lepeletier & Alabama argillacea $(\mathrm{Hb})$. & St Vincent \\
\hline Polistes cinctus cinctus Lepeletier & Calpodes ethlius (Stoll) & St Vincent \\
\hline Rodolia cardinalis (Muls.) & Icerya purchasi Mask. & $\begin{array}{l}\text { Bahamas, Cayman Islands, } \\
\text { Montserrat, St Kitts and Nevis }\end{array}$ \\
\hline Tiphia parallela F. Sm. & $\begin{array}{l}\text { Phyllophaga antiguae (Arr) } \\
\text { and Phyllophaga sp. }\end{array}$ & Antigua \\
\hline
\end{tabular}

increased strongly. In a report prepared by CABI (Kairo et al., 2003b), a shortlist of 23 major invasive species threats was presented occurring in five or more (up to 16 for some species) Caribbean countries. Kairo et al. (2003b) concluded that an approach which minimizes the entry of alien species or allows for early detection before establishment and spread would considerably reduce the overall cost of elimination or management. However, such an approach demanded cooperation among the many countries in the Caribbean region concerning trading of agricultural commodities as well as tourist activities, an issue not easily resolved. Still, at least two early detection programmes involving region-wide collaboration appear to have resulted in successful biocontrol: that of the pink hibiscus mealybug Maconellicoccus hirsutus (Green) and the papaya mealybug Paracoccus marginatus Williams \& Granara de Willink. In both programmes, the introduction of exotic parasitoid species resulted in mealybug population density reductions ranging from $82 \%$ to $97 \%$. Early programme development allowed for quick technology transfer to newly infested Caribbean islands and to the USA mainland within 30 days of being found infested (Meyerdirck and DeChi, 2003).
Examples of other invasive species that have entered and for which biocontrol attempts have been made are the whitefly Bemisia tabaci (Gennadius), the citrus leaf miner Phyllocnistis citrella Stainton and the citrus blackfly $A$. woglumi, the imported red fire ant Solenopsis invicta Buren, the coconut whitefly Aleurodicus pulvinatus (Maskell), the red palm mite Raoiella indica Hirst and the melon thrips Thrips palmi Karny. The most important successes are listed in Table 27.2.

\subsubsection{Biological control of pests of citrus}

\section{Citrus leaf miner}

BAHAMAS. Ageniaspis citricola Logviniskaya was introduced into the Bahamas in 1996 for control of P. citrella (Kairo et al., 2003a).

\section{Citrus blackfly}

ST KITTS AND NEVIS. Colmenarez et al. (2018) mentioned that in the 1990s Dominica, Guyana, 
Table 27.2. Biological control successes achieved after 1980 in the Remaining Caribbean Islands.

\begin{tabular}{|c|c|c|}
\hline Biological control agent & Pest & Remaining Caribbean Island \\
\hline $\begin{array}{l}\text { Amitus hesperidum, Encarsia } \\
\text { perplexa }\end{array}$ & Aleurocanthus woglumi Ashby & St Kitts and Nevis \\
\hline Anagyrus kamali Moursi & Maconellicoccus hirsutus (Green) & Several islands \\
\hline $\begin{array}{l}\text { Apoanagyrus spp., Anagyrus spp., } \\
\text { Acerophagus spp. }\end{array}$ & $\begin{array}{l}\text { Paracoccus marginatus Williams } \\
\text { \& Granara de Willink }\end{array}$ & Several islands \\
\hline Native natural enemy complex & Aleurodicus pulvinatus (Maskell) & Several islands \\
\hline Native natural enemy complex & Planococcus minor Maskell & Several islands \\
\hline
\end{tabular}

French Guiana and St Kitts and Nevis experienced the resurgence of citrus blackfly $A$. woglumi, resulting in serious problems in citrus. A classical biocontrol programme was initiated to control the pest, with the introduction of Amitus hesperidum Silvestri and Encarsia perplexa Huang and Polaszek, resulting in control of the pest (White et al., 2005).

\subsubsection{Biological control of pests of coconut}

\section{Coconut whitefly}

NEVIS. The coconut whitefly $A$. pulvinatus is a serious pest of coconut and many ornamental species and caused serious problems on Nevis, though on several other Caribbean islands it is kept under natural biocontrol. Natural enemies were also found on Nevis, but they did not sufficiently control the whitefly. In an FAO-supported project, a survey for natural enemies was carried out in Trinidad and Tobago in 1995. The natural enemy complex attacking Aleurodicus spp. includes species of Aphelinidae in two genera (Encarsiella and Encarsia), one Encyrtidae (Metaphycus sp.) and several coccinellid species of the genus Nephaspis (Kairo et al., 2001); Encarsiella sp. D was introduced into Nevis in 1998 and has established.

\section{Red palm mite}

The red palm mite $R$. indica was first reported in the Caribbean in 2004. It is now widely distributed in the region and may cause severe damage to Araceae (in particular, coconut Cocos nucifera L.), but also to Musaceae and other plants. Amblyseius largoensis (Muma) is very common on coconut palms and may play a role in reducing palm mite populations. Also, entomopathogenic fungi, possibly Hirsutella spp., have been found to infect the palm mite. However, natural biocontrol by these beneficial organisms is insufficient. Colmenarez et al. (2014) made an inventory of entomopathogenic fungi associated with red palm mite in the Caribbean, including Antigua, St Kitts and Nevis. Of the 27 fungal isolates identified, three belonging to Simplicillium sp., representing a possible undescribed taxon, and Penicillium sp. might be interesting for future evaluation. Simplicillium isolates (formerly identified as Verticillium) have been used as commercial biocontrol agents to control pests such as whiteflies, thrips and aphids. According to Colmenarez et al. (2014), it seems that the level of control by these naturally occurring entomopathogenic fungi is low.

\section{Coconut scale}

Many introductions of coccinellids were made into Caribbean islands for the control of the coconut scale Aspidiotus destructor Sign. between 1937 and 1973, but with little success, except in St Kitts and Nevis (see Section 27.2). The predatory beetle Cybocephalus nipponicus EndrödyYounga of Asia was introduced into North America from 1989 and released in Florida in 1999 (Smith and Cave, 2006). It has been reported from the Cayman Islands and St Kitts and Nevis, among others, attacking the coconut scale (Smith and Cave, 2007).

\subsubsection{Biological control of pests of other tree crops and ornamentals}

\section{Papaya mealybug}

The papaya mealybug P. marginatus causes serious damage to tropical fruit, especially papaya and hibiscus, and its host range includes at least 
55 plant species. In the Remaining Caribbean Islands it occurs on Antigua, Montserrat, Nevis, St Kitts, Sint Maarten and the Virgin Islands. This mealybug is supposed to have been introduced to the Caribbean around 1993, since when it has spread over most of the Caribbean archipelago (Miller et al., 1999; Meyerdirck and DeChi, 2003). The potential for successful biocontrol was rated high, as the mealybug seemed under natural control in Mexico and five parasitoids had already been collected there: Anagyrus californicus (Compere), Anagyrus loecki Noyes and Menezes, Acerophagus papayae Noyes and Schauff, Pseudleptomastix mexicana Noyes and Schauff. and Pseudaphycus angelicus (Howard). The parasitoids were screened by the US Department of Agriculture's Agriculture Research Service (USDA-ARS) and an environmental assessment was made. The parasitoids were then shipped to Puerto Rico, where they were reared and field released, resulting in complete biocontrol (see Chapter 26: Puerto Rico). A similar success was obtained in the Dominican Republic (see Chapter 12: Dominican Republic) (Meyerdirck and DeChi, 2003). Cryptolaemus montrouzieri was introduced into Antigua in 1998 for control of the papaya mealybug (Kairo et al., 2003a).

\section{Pink hibiscus mealybug}

Pink hibiscus mealybug $M$. hirsutus attacks the new flush growth, young shoots, flowers and fruits of a wide range of plants, particularly those in the family Malvaceae, but also in crops like cacao, okra, mango, plums, sorrel and soursop Annona muricata L. and trees such as samaan, teak and blue mahoe (Kairo et al., 2000; Clarke-Harris and Lauckner, 2005). The pest was first reported in the Caribbean in 1994 in Grenada and by the beginning of 2001 it had spread to over 25 territories, from Guyana and Venezuela in the south to Bahamas (see also country-specific chapters), with 28 Caribbean territories having the pest in 2003 (ClarkeHarris and Lauckner, 2005). A programme was developed for the introduction, multiplication and release of three ladybird beetles, C. montrouzieri, Scymnus coccivora Aiyyar and Nephus regularis Sicard. These ladybirds were imported into the region in 1996 and local natural enemies were studied as well (Clarke-Harris and Lauckner, 2005). Biocontrol for the pink hibiscus mealybug was first developed in St Kitts and Nevis between 1995 and 1997 and was eventually based on releases of Anagyrus kamali Moursi. This parasitoid has since been transferred to several of the Remaining Caribbean Islands (Meyerdirck and DeChi, 2003). In all islands where biocontrol was implemented, this resulted in successful control, which is summarized in Kairo et al. (2000).

ANTIGUA. A. kamali was introduced into Antigua in 2001 for control of hibiscus mealybug (Kairo et al., 2003a).

BAHAmas. The Bahamas were found to be infested in November 2000. After A. kamali parasitoid introduction, the mealybug population density was reduced within a year by $82 \%$ (Meyerdirck and DeChi, 2003).

CURAÇAO. A. kamali was introduced into Curaçao in 1999 for control of hibiscus mealybug (Kairo et al., 2003a).

GRENADA. The pink hibiscus mealybug appeared in the Caribbean for the first time in Grenada in 1994 and the first biocontrol project was an FAO Technical Cooperation Project started in 1995, followed by a 15-country FAO funded project (Kairo et al., 2000). Interestingly, it was one of the first projects for which ISPM No. 3 (see below) was applied. While there were risks associated with some of the agents, particularly the generalist mealybug predator $C$. montrouzieri, these were considered of less importance than those posed by the pest and thus introductions were made in 1997 (Cock, 2002). In 1998, the predator S. coccivora was introduced. Also the parasitoids A. kamali (1996; origin China and Hawaii) and Gyranusoidea indica Shafee, Alam \& Argarwal (1998, origin Egypt) were introduced, sourced through the USDA. Complete biocontrol of the pink hibiscus mealybug was obtained after these natural enemy releases.

montSerRAT. A. kamali was introduced into Montserrat in 1997 (Kairo et al., 2003a).

ST KITTS. A. kamali and S. coccivora (both in 1996) and C. montrouzieri (1997) were introduced into St Kitts (Kairo et al., 2003a). By January of 1998, 
the parasitoid A. kamali had reduced the mealybug population by $92 \%$ (Meyerdirck and DeChi, 2003).

ST LUCIA. A. kamali and C. montrouzieri were introduced into St Lucia in 1997 (Kairo et al., 2003a).

ST VINCENT. A. kamali was introduced into St Vincent in 1997 (Kairo et al., 2003a).

VIRGIN ISLANDS. Pink hibiscus mealybug was first found in 1997 and after releases of parasitoid A. kamali, the mealybug populations decreased by more than 90\% (Meyerdirck and DeChi, 2003).

\section{Passion vine mealybug}

The passion vine mealybug Planococcus minor Maskell, native to Asia, is a polyphagous pest with a host range exceeding 200 plant species and has been recorded from several countries in the Caribbean (Kairo et al., 2008), including Antigua, Grenada, St Lucia and the Virgin Islands. In the Caribbean, it seems that this mealybug is restricted to only a few plants, with cocoa as important host. Currently, mealybug populations are low at all locations and the pest is attacked by several native predators and parasitoids (Table 2 in Kairo et al., 2008; Roda et al., 2013).

\subsubsection{Biological control of pests of cotton}

\section{Whiteflies}

In the Caribbean, three species of whitefly, Trialeurodes abutilonea (Haldeman), T. vaporariorum (Westwood) and B. tabaci, are known to be able to transmit geminiviruses in addition to the direct damage they may cause. Bemisia tabaci is the most damaging of these three, feeding on more than 500 species of plants, including at least 17 crops in the Caribbean. In 2002, CARDI initiated a project on integrated pest management (IPM) of whitefly, including biocontrol components. Information provided in Clarke-Harris and Lauckner (2005) showed that research on whitefly biocontrol was done in Grenada and St Kitts and Nevis.

\subsubsection{Biological control of pests of cruciferous crops}

\section{Diamondback moth}

ST KITTS. Based on a 2-year field study on St Kitts, Yencho et al. (1987) reported that presence of high densities of the parasitoid A. plutella delayed the time to the first pesticide spray and that parasitism levels exceeding 25-35\% may control diamondback moth.

\subsubsection{Biological control of pests of sweet potato}

\section{Sweet potato weevils}

Sweet potato Ipomoea batatas (L.) Lam. is one of the most important food crops in developing countries, including much of the Caribbean basin. Insect pests rank as one of the top three production problems for sweet potato, and the sweet potato weevil Cylas formicarius (Summers) is the most important pest in the region. In some Caribbean islands (e.g. St Vincent), the West Indian sweet potato weevil Euscepes postfasciatus (Fairmaire) is the predominant weevil species (Jackson et al., 2002). Jackson et al. (2002) provided a list of other pests occurring on sweet potato in the Caribbean region and gave an overview of IPM methods to control pests on this crop, including biocontrol. They remarked that natural biocontrol agents should be conserved through judicious use of pesticides. Predatory ants, nematodes and entomopathogens (especially B. bassiana [Bals.] Vuill. and M. anisopliae) were mentioned as potentially effective agents against weevils in sweet potato (Jackson et al., 2002).

\subsubsection{Biological control of pests of other vegetable and field crops}

\section{Phytophagous mites}

Frank et al. (1992) published distribution records for Oligota minuta Cameron, a polyphagous predator of arthropods, including tetranychid 
mites such as cassava green mite Mononychellus tanajoa (Bondar). They mentioned that this predator was found in Antigua, the Bahamas, Montserrat, Nevis and the Virgin Islands, among others.

\subsubsection{Biological control of pests of humans and domestic animals}

\section{Mosquitoes vectoring human diseases}

ANTIGUA. Fifteen Caribbean strains of copepods, including a strain from Antigua, were assessed for their predation ability against mosquito larvae by Rawlins et al. (1997) in order to find a biocontrol tool for the dengue vector Ae. aegypti. Mesocyclops sp. from Antigua showed a high percentage of predation of $A$. aegypti, but not of Culex quinquefasciatus Say. According to Rawlins et al. (1997), the availability of mosquitolarvivorous copepods in the Caribbean region offered a good promise for control of Ae. aegypti now that appropriate strains of Macrocyclops and Mesocyclops had been identified.

\section{Fire ants}

The fire ants Solenopsis richteri Forel and Solenopsis invicta Buren occur in a number of Caribbean islands, including Antigua, the Bahamas and the Virgin Islands, and it is foreseen that more islands will be infested in the future (Williams and deShazo, 2004). Fire ants are aggressive when their nests are disturbed and cause painful stings to humans and other animals. In South America, 40 species of parasitoids, pathogens, predators and competitors are believed to be the major controls of fire ant density and a review of natural enemies of fire ants was published by Williams et al. (2003). In the USA, biocontrol of fire ants has recently been evaluated; and decapitating parasitic flies native to South America (Pseudacteon tricuspis Borgmeier, Pseudacteon curvatus Borgmeier and Pseudacteon litoralis Borgmeier) as well as a protozoan pathogen (Thelohania solenopsae Knell, Allen \& Hazard ) might be useful for fire ant control in the Caribbean (Williams and deShazo, 2004).

\subsection{New Developments of Biological Control in the Remaining Caribbean Islands}

Two recent developments related to biocontrol in the Remaining Caribbean Islands - regulations for import of exotic biocontrol agents and the implementation of Farmers Field Schools - are summarized below.

\subsubsection{The effect of regulations on implementation of biological control in the Caribbean}

During the past 40 years, guidelines and regulations have been developed concerning import and release of exotic natural enemies, which are discussed in Chapters 1 and 32. Kairo et al. (2003a) evaluated the effect of one of these guidelines, the Code of Conduct for the Import and Release of Exotic Biological Control Agents, which was endorsed by members of the FAO in 1995 and became the International Standards for Phytosanitary Measures (ISPM) No. 3 under the International Plant Protection Convention in 1996 (IPPC, 1996; FAO, 1997). The Code of Conduct was developed as a result of growing awareness that introduction of exotic natural enemies without proper evaluation of the risks might result in negative impacts to the environment and beneficial and other valued organisms. The Code was considered particularly important for countries with limited expertise in biocontrol; and the preparation of a dossier prior to each biocontrol agent introduction according to the Code was considered essential. The latest update of ISPM 3, now 'Guidelines for the export, shipment, import and release of biological control agents and other beneficial organisms', was published in 2017 (IPPC, 2017).

Kairo et al. (2003a, p. 15N) used several biocontrol projects from the Caribbean region to review the use of the Code of Conduct during the first years after its implementation, and they concluded that:

Either ISPM No. 3 or similar national procedures were applied in most cases to support decisions regarding import and release of exotic biological control agents since 1996. It has provided a mechanism for formalizing current good practice and provided internationally accepted 
standards to countries with little experience in implementing biological control. It provides a good basis for facilitation of regional projects.

\subsubsection{Implementation of Farmers Field Schools in the Caribbean region}

Farmers Field Schools (FFSs) use participatory and ecological approaches for field testing and local adaptation of innovative practices and knowledge in different technical areas. They have played and still play an important role in enabling farmers to apply IPM and biocontrol, thus becoming less dependent on chemical pesticides in several parts of the world. The FFS philosophy, its way of work and evaluation of several large projects are described in Van den Berg and Jiggins (2007) and Lopez and Ramroop (2014). FFSs were introduced into the Caribbean during 2002-2003 to address the indiscriminate use of toxic pesticides and the consequent negative impact on the environment and human health. Since then, they have spread within the Caribbean (Paul, 2016; Paul et al., 2016). The FAO Sub-regional Office for the Caribbean in Barbados recently analysed progress made by FFSs in the Caribbean. Paul et al. (2016, p. 1) summarized the main results as follows:

In 2002, Trinidad and Tobago was the first country to be introduced to the FFS methodology, with the implementation of a Training of Master Trainers for participants from six countries (Dominica, Dominican Republic, Haiti, Jamaica, Suriname and Trinidad and Tobago) under an EU-funded Regional Pilot Project. In 2003, the six countries embarked on a Training of Trainers under the same project. Over the next 3-4 years, field schools were organized in some of the project countries (e.g. Dominica, Suriname and Trinidad and Tobago). Guyana successfully mobilized funding from the Guyana Rice Development Board (GRDB) to launch a commodity (rice) FFS in June 2003. St Lucia launched a FFS-TOT as part of an EU-funded project implemented by FAO. Antigua did likewise in 2013 with the launch of the Zero Hunger Challenge Initiative and St Kitts and Nevis became engaged in May 2015, through the FAO project TCP/STK/3501.

Since the start of FFSs in the Caribbean, thousands of farmers have been trained. Lopez and Ramroop (2014) provided information on seven case studies, including the effect of FFSs on IPM, and concluded (p. 21) that:
... field schools are still a relatively new concept in some Caribbean countries. The process of developing an understanding and trust amongst the different stakeholders is gradual, but the approach is gaining support from government and communities. The promotion of farmer participatory approaches is in keeping with the commitment of most countries for an improved approach to pest management and to the delivery of agricultural extension services to farmers in the Caribbean.

\subsubsection{Final remarks}

Chapter 1 presented an overview of organizations that study, implement or coordinate biocontrol activities in the region. In the Caribbean basin, the following organizations are involved: the Trinidad and Tobago Station of the Centre for Agriculture and Biosciences International (CABI), the Caribbean Agricultural Research and Development Institute (CARDI), the Inter-American Institute for Cooperation on Agriculture (IICA), the Tropical Agriculture Research and Higher Education Center (CATIE), the International Regional Organization for Plant Protection and Animal Health (OIRSA), and the United Nations Food and Agriculture Organization Regional Office for Latin America and the Caribbean (FAO).This list of organizations is impressive, but taking the large number of invasive organisms that have established in the Caribbean into account, and the exotic species expected to establish in the near future (Kairo et al., 2003b; Clarke-Harris and Lauckner, 2005), available funding for development of IPM and biocontrol programmes seems insufficient for finding sustainable pest control solutions. Other factors hampering implementation of biocontrol are the poorly funded and limited size of extension services, which results in farmers obtaining pest control information only from chemical companies. Also, pesticide regulations are often not enforced. The result is that pesticide misuse and overuse are common. An important recent factor stimulating implementation of IPM and biocontrol in the Caribbean region concerns the strict export demands for the North American and European market, which prohibit the use of large groups of pesticides. 


\section{References}

(References with grey shading are available as supplementary electronic material)

Baker, P.S., Khan, A., Mohyuddin, A.I. and Waage, J.K. (1992). Overview of biological control of Lepidoptera in the Caribbean. Florida Entomologist 74(4), 477-483.

Boughton, A.J., Mendez, M.A., Francis, A.W., Smith, T.R., Osborne, L.S. and Mannion, C.M. (2015) Host stage suitability and impact of Encarsia noyesi (Hymenoptera: Aphelinidae) on the invasive rugose spiraling whitefly, Aleurodicus rugioperculatus (Hemiptera: Aleyrodidae), in Florida. Biological Control 88, 61-67.

CIA (2018a) The World Factbook: Antigua and Barbuda. Available at: https://www.cia.gov/library/ publications/the-world-factbook/geos/ac.html (accessed 22 July 2019).

CIA (2018b) The World Factbook: Aruba. Available at: https://www.cia.gov/library/publications/the-worldfactbook/geos/aa.html (accessed 22 July 2019).

CIA (2018c) The World Factbook: Curacao. Available at: https://www.cia.gov/library/publications/theworld-factbook/geos/uc.html (accessed 22 July 2019).

CIA (2018d) The World Factbook: Bahamas. Available at: https://www.cia.gov/library/publications/theworld-factbook/geos/bf.html (accessed 22 July 2019).

CIA (2018e) The World Factbook: Cayman Islands. Available at: https://www.cia.gov/library/publications/ the-world-factbook/geos/cj.html (accessed 22 July 2019).

CIA (2018f) The World Factbook: Grenada. Available at: https://www.cia.gov/library/publications/theworld-factbook/geos/gj.html (accessed 22 July 2019).

CIA (2018g) The World Factbook: Montserrat. Available at: https://www.cia.gov/library/publications/theworld-factbook/geos/mh.html (accessed 22 July 2019).

CIA (2018h) The World Factbook: St Kitts and Nevis. Available at: https://www.cia.gov/library/publications/ the-world-factbook/geos/sc.html (accessed 22 July 2019).

CIA (2018i) The World Factbook: St Lucia. Available at: https://www.cia.gov/library/publications/the-worldfactbook/geos/st.html (accessed 22 July 2019).

CIA (2018j) The World Factbook: St Vincent. Available at: https://www.cia.gov/library/publications/theworld-factbook/geos/vc.html (accessed 22 July 2019).

CIA (2018k) The World Factbook: Virgin Islands. Available at: https://www.cia.gov/library/publications/ the-world-factbook/geos/vq.html (accessed 22 July 2019).

Clarke-Harris, D.O. and Lauckner, F.B. (2005) Research efforts to deal with invasive species in the Caricom region. Proceedings of the Caribbean Food Crops Society 41(1), 125-150.

Cock, M.J.W. (ed.) (1985) A Review of Biological Control of Pests in the Commonwealth Caribbean and Bermuda up to 1982. Technical Communication No. 9, Commonwealth Institute of Biological Control. Commonwealth Agricultural Bureaux, Farnham Royal, UK.

Cock, M.J.W. (2002) Risks of non-target impact versus stakeholder benefits in classical biological control of arthropods: selected case studies from developing countries. In: Van Driesche, R. (ed.) Proceedings of the First International Symposium on Arthropod Biological Control, Honolulu, Hawaii, USA, 13-18 January 2002. USDA Forest Service, Morgantown, West Virginia, pp. 25-33.

Colmenarez, Y., Moore, D., Polar, P. and Vasquez, C. (2014) Population trends of the red palm mite, Raoiella indica Hirst (Acari: Tenuipalpidae) and associated entomopathogenic fungi in Trinidad, Antigua, St Kitts and Nevis and Dominica. Acarologia, 54(4), 433-442. DOI: 10.1051/acarologia/20142141

Colmenarez, Y.C., Corniani, N., Mundstock, J.S., Sampaio, M.V. and Vásquez, C. (2018) Use of Parasitoids as a Biocontrol Agent in the Neotropical Region: Challenges and Potential. DOI: 10.5772/intechopen. 80720. Available at: https://www.intechopen.com/online-first/use-of-parasitoids-as-a-biocontrol-agent-inthe-neotropical-region-challenges-and-potential (accessed 25 July 2019).

FAO (1997) Code of Conduct for the Import and Release of Exotic Biological Control Agents. Biocontrol News and Information 18, $119 \mathrm{~N}-124 \mathrm{~N}$

Frank, J.H., Bennett, F.D. and Cromroy, H.L. (1992) Distribution and prey records for Oligota minuta (Coleoptera: Staphelinidae), a predator of mites. Florida Entomologist 75(3), 376-380.

Gerberg, E.J. and Visser, W.M. (1978) Preliminary field trial for the biological control of Aedes aegypti by means of Toxorhynchites brevipalpis, a predatory mosquito larva. Mosquito News 38(2), 197-200.

IPPC (1996) Code of Conduct for the Import and Release of Exotic Biological Control Agents. International Standards for Phytosanitary Measures No. 3. International Plant Protection Convention. Food and Agriculture Organization of the United Nations (FAO), Rome. 
IPPC (2017) Guidelines for the export, shipment, import and release of biological control agents and other beneficial organisms. International Standards for Phytosanitary Measures No. 3. International Plant Protection Convention. Food and Agriculture Organization of the United Nations (FAO), Rome. Available at: https://www.ippc.int/static/media/files/publication/en/2017/05/ ISPM_03_2005_En_2017-0523_PostCPM12_InkAm.pdf (accessed 17 May 2019).

Jackson, D.M., Bohac, J.R., Dalip, K.M., Lawrence, J., Clarke-Harris, D., McComie, L., Gore, J., McGlashan, D., Chung, P., Edwards, S., Tolin, S. and Edwards, C. (2002) Integrated Pest Management of sweetpotato in the Caribbean. Proceedings of the $1^{\text {st }}$ International Symposium on Sweetpoptato. Acta Horticultura $583,143-154$.

Kairo, M.T.K., Pollard, G.V., Peterkin, D.D. and Lopez, V.F. (2000) Biological control of the hibiscus mealybug, Maconellicoccus hirsutus Green (Hemiptera: Pseudococcidae) in the Caribbean. Integrated Pest Management Reviews 5, 241-254.

Kairo, M.T.K., Lopez, V.F., Pollard, G.V. and Hector, R. (2001) Biological control of the coconut whitefly, Aleurodicus pulvinatus, in Nevis. Biocontrol News and Information 22, $45 \mathrm{~N}-50 \mathrm{~N}$.

Kairo, M.T.K., Cock, M.J.W. and Quinlan, M.M. (2003a) An assessment of the use of the Code of Conduct for the Import and Release of Exotic Biological Control Agents (ISPM No. 3) since its endorsement as an international standard. Biocontrol News and Information 24, 15N-27N.

Kairo, M.T.K., Cheeseman, O.D., Ali, B.S., Haysom, K. and Murphy, S.T. (2003b) Dangerous invasive species threatening or with a foothold in the Caribbean. Proceedings of the Caribbean Food Crops Society 39(1), 12-22.

Kairo, M.T.K., Francis, A. and Roda, A. (2008) Developing strategic research for biological control of new pest threats: the passion vine mealybug, Planococcus minor as a case study. Proceedings of the Caribbean Food Crops Society 44(1), 118-123.

Landenweb (2019) Bonaire. Available at: https://www.landenweb.nl/bonaire/economie/ (accessed 21 July 2019).

Lopez, V. and Ramroop, D. (2014) Escuelas de campo de agricultores en el Caribe [Farmer Field Schools in the Caribbean]. In: Sacedo, S. and Guzmán, L. Agricultura familiar en América Latina y el Caribe. Organización de las Naciones Unidas para la Alimentación y la Agricultura (FAO) Santiago, Chile, pp. 233-252. Available at: http://www.fao.org/docrep/019/i3788s/i3788s.pdf (accessed 17 May 2019).

Meyerdirck, D.E. and DeChi, L.W. (2003) Models for minimizing risks of dangerous pests: the pink hibiscus mealybug and papaya mealybug. Proceedings of the Caribbean Food Crops Society 39(1), 12-22.

Miller, D.R., Williams, D.J. and Hamon, A.B. (1999) Notes on a new mealybug (Hemiptera: Coccoidea: Pseudococcidae) pest in Florida and the Caribbean: the papaya mealybug, Paracoccus marginatus Williams and Granara de Willink. Insectamundi 13(3-4), 179-181.

Paul, R. (2016) Stocktaking of Farmer Field Schools in the Caribbean. Food and Agriculture Organization Sub-regional Office for the Caribbean, Barbados.

Paul, R., Lopez, C. and Allara, M. (2016) Stocktaking of farmer field schools in the Caribbean. Paper presented at the 52nd CFCS Annual Meeting, Guadeloupe, July 10-16, 2016.

Rawlins, S.C., Martinez, R., Wiltshire, S., Clarke, D., Prabhakar, P. and Spinks, M. (1997) Evaluation of Caribbean strains of Macrocyclops and Mesocyclops (Cyclopoidae: Cyclopidae) as biological control tools for the dengue vector Aedes aegypti. Journal of the American Mosquito Control Association 13, 18-23.

Roda, A., Francis, A., Kairo, M.T.K and Culik, M. (2013) Planococcus minor (Hemiptera: Pseudococcidae): bioecology, survey and mitigation strategies. In Peña, J.E. (ed.) Potential Invasive Pests of Agricultural Crops. CAB International, Wallingford, UK, pp. 288-300.

Smith, T.R. and Cave, R.D. (2006) The life history of Cybocephalus nipponicus a predator of the cycad aulacaspis scale, Aulacaspis yasumatsui (Homoptera: Diaspididae). Proceedings of the Entomological Society of Washington 108, 905-916.

Smith, T.R. and Cave, R.D. (2007) The Cybocephalidae (Coleoptera) of the West Indies and Trinidad. Annals of the Entomological Society of America 100, 164-172.

van den Berg, H. and Jiggins, J. (2007) Investing in farmers - the impacts of farmer field schools in relation to Integrated Pest Management. World Development 35(4), 663-686.

White, G.L., Kairo, M.T.K. and Lopez, V. (2005) Classical biological control of the citrus blackfly Aleurocanthus woglumi by Amitus hesperidum in Trinidad. BioControl 50, 751-759.

Wikipedia (2019a) Bonaire. Available at: https://en.wikipedia.org/wiki/Bonaire (accessed 29 July 2019).

Wikipedia (2019b) Saba. Available at: https://en.wikipedia.org/wiki/Saba (accessed 29 July 2019).

Wikipedia (2019c) Sint Eustatius. Available at: https://en.wikipedia.org/wiki/Sint_Eustatius (accessed 29 July 2019). 
Wikipedia (2019d) Sint Maarten. Available at: https://en.wikipedia.org/wiki/Sint_Maarten (accessed 29 July 2019).

Williams, D.F., Oi, D.H., Porter, S.D., Pereira, R.M. and Briano, J.A. (2003) Biological control of imported fire ants. American Entomologist 49, 144-155.

Williams, D.F. and deShazo, R.D. (2004) Biological control of fire ants: an update on new techniques. Annals of Allergy, Asthma \& Immunology 93, 15-22.

Yencho, G.C., Blanchette, T. and Dolphin, E. (1987) Diamondback moth, Plutella xylostella (L.), control studies on cabbage in St Kitts, 1987. $23^{\text {rd }}$ Annual Meeting of the Caribbean Food Crops Society, Antigua, pp. 190-196. 